\title{
The Shoushtari Poem "Priceless Youth"
}

\author{
Introduction and translation by Nadia Ghazanfari-Moghaddam \\ Ferdowsi University of Mashhad, Iran
}

\begin{abstract}
Mohammad Ali Mehdi-Abadi (known as Salehe) was born in Shoushtar, Ahwaz (located in the far south-western part of Iran). He was raised in a well-educated family and took after them in his care for literature. Salehe adored his hometown Shoushtar and this inspired him to gather Shoushtari folklore, poems, stories, traditions, and even music, combining them into a fine collection with a Shoushtari local color. Salehe named his collection "Dibaye Shoushtar" which refers to a cloth called "Diba" which was once made in Shoushtar and was very popular among the merchants of its time.
\end{abstract}

One of the most outstanding features of this collection is the preservation of Shoushtari dialect. The folklore, poems and even the music rhythms are all transcribed and explained in detail for even the non-native reader. The vernacular vocabulary, grammatical structure, the common pronunciation and the intonations of this Persian dialect are kept untouched. In some other poems of this collection, the historical events of Shoushtar are also called into attention. Unfortunately, as the new Shoushtari generation has chosen to follow "standardization" in both lifestyle and language, this geographical dialect has begun to fade away. Accordingly, motivated by an urge to attain "modernization", the very fact of following the "standard" trend becomes a symbol of prestige and it turns into a somewhat "required-criteria" for one's acceptance in a social group. Consequently, the universal gradual shift towards standardization will eliminate potential differences and cause "homogeneity", leading to a colony composed of sheer copies of copies, all repeating the same trends and patterns over and over. The most disruptive effect of this can perhaps be the derogation of dialects and at a radical case, "dialect death".

In the homogenizing policies of the nation-state, a super-language is imposed on all domains of life, pushing dialects to the margins and representing dialect literature as minor. Therefore, "the strength of dialect," notes Bonaffini, "lies in its essential 'otherness,' ... in its position of eccentricity with respect to the national language, in its different history" (279). This said, it is salient for translation to take a more determined shift towards the translation and transmission of literary pieces written in rare languages and dialects in order to share various perspectives and experiences. Hereby, we can hope that a possible balance could be gradually achieved and all literary pieces could have the opportunity to be shared with a larger readership. This was my intention of selecting this poem for translation.

As for the translation procedure, I have tried to be eclectic and apply strategies that could best contribute to a more effective intercultural communication of the source text (ST) content and alongside transmit its general form. When the poet speaks the same language as the readers', both by tongue and heart, $\mathrm{s} /$ he can be sure that his/her message will sit comfortably in the heart of its audience. Then, a thought can be shared, a feeling provoked, an experience drawn, and a story retold. The same stands for the language of translation. (After all, the translator does reflect 
his/her own ideological, schematic, and emotional response to the original text (as a reader and mediator) in his/her own "rewriting" of the ST).

In order to translate this piece, I preferred to use Standard English which is as Yule defines " ... the variety we normally try to teach to those who want to learn English as a second or foreign language"(240). Yule also states that "[Standard English] is the version we believe is found in printed English in newspapers and books, is widely used in the mass media and is taught in most schools" (240).

As every dialect carries its own local color, translating it into another dialect would naturally involve the transfer of the substituting dialect's emotional, connotative, figurative, and symbolic meanings as well - and sometimes these do not match the ST dialect's contents. Thus, the solution to substitute any possible TL dialect in order to illustrate that the ST has been composed with a certain dialect could be rather disrupting regarding the semantics of the literary piece, emotional impact, and the author's intention. For example, translating this Shoushtari poem into an Irish dialect would most likely lead to a cultural shock in both the Persian reader (who compares the original with the translated text) and also the Irish reader - or anyone who is familiar with Irish or Persian context and their local color. Therefore, the connotative and cultural implications and the figurative language will not be what they were acclimated to be. Therefore, I chose to translate Shoushtari dialect into "Standard English" to avoid any chance of misinterpretations and especially misrepresentations.

The lexes and grammatical combinations have all been selected with great care to preserve the referential, connotative, and emotional meaning of each lexical item in the poem and also to transmit its cultural intention, and its setting as far as possible. My aim was to communicate with my reader via a familiar language, to establish a friendly atmosphere and share this piece while also evoking their emotional response to it (just like the poet had intended for the poem's reader).

\section{Priceless Youth}

I have an axiom for you, my young child, my pearl

Trade not your youth, the prime of your life, for the world

Your youth, is a treasure, an award

Trade not this priceless jewel, not even for Qaroun's ${ }^{1}$ hoard

Be yours, my young child; let all Solayman's ${ }^{2}$ estate

Alas! Trade not your youth even for an empire's estate

My young child, oh thee with thy blissful croon and all youth's beauty

Trade not your youth even for Yousof of Kanaan's ${ }^{3}$ extreme beauty

\footnotetext{
${ }^{1}$ Qaroun was a rich famous man in Islamic religion, and Persian literature and culture for being in the possession of excessive treasure, jewelry and assets.

${ }^{2}$ Solayman was famous in Islamic religion and Persian literature and culture for being in possession of many estates and assets.

${ }^{3}$ Yousof of Kanaan was famous in Islamic religion and Persian literature and culture for his extreme beauty and handsomeness. He was a (an) adios young man.
} 
Let not your life be wasted drowsily

Trade not this priceless treasure dreamily

Seek knowledge, become sophisticated, and wisdom you should gain

Consult with the astute and trade not your youth for the words of an insane

Alas! My young child, let not thy youth squander

Trade youth not, not even for the company of a rambler

Let not your youth to chance, to destiny

Trade not this treasure, for a fantasm falsity

Aging comes along anon, and with it regret

Trade not your youth easily to not lament

Life becomes a prison, gradually to the aged

Alas, trade not this blithe rosary for a cage

Older you become, assure, perceive you will my words

By the youth people, trade not your life for worthless awards

As long as I live, I (Salehe1) will constantly promulgate

Life is God's gift; let not the prime of your life dissipate

$$
\begin{aligned}
& \text { د ارم سخنـى هـى تـو جهو ون اى كـهـ كَرى كَوش }
\end{aligned}
$$

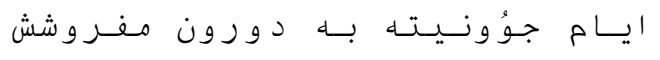

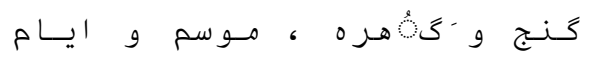

$$
\begin{aligned}
& \text { جو ونس } \\
& \text { اى كَنـج بـهـ د ارويسي قـارون مـفـروشش } \\
& \text { اى مـلـك سلـيمـون كـنـن كــشه بـه نـومـت }
\end{aligned}
$$

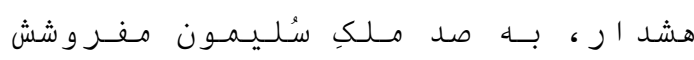

$$
\begin{aligned}
& \text { اى صاحب او ازِ خهوش و حسنِ قـشنحى } \\
& \text { جى د اوود و جهى يـوسف كـنــون مفـروشش }
\end{aligned}
$$

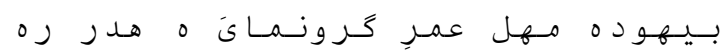

$$
\begin{aligned}
& \text { اى كَوهـرِ نـايـابَ تــو ارزون مـفـروشش } \\
& \text { تسصيلٍ سو اد و طلب علم و علـوم كن } \\
& \text { دش در كَفِ دونسا وُُ بـهـ نـادون مفــروشش } \\
& \text { هـر دو تسى يـتـه حَش ، كـه مـبـاد ا دزنسش وت } \\
& \text { دلـده ، وُ بــهـ نـــــاب رفـيقـون مفـروشش }
\end{aligned}
$$

\footnotetext{
${ }^{1}$ The name of the poet of this poem: Mohammad Ali Mehdi Abadi known as "Salehe".
} 


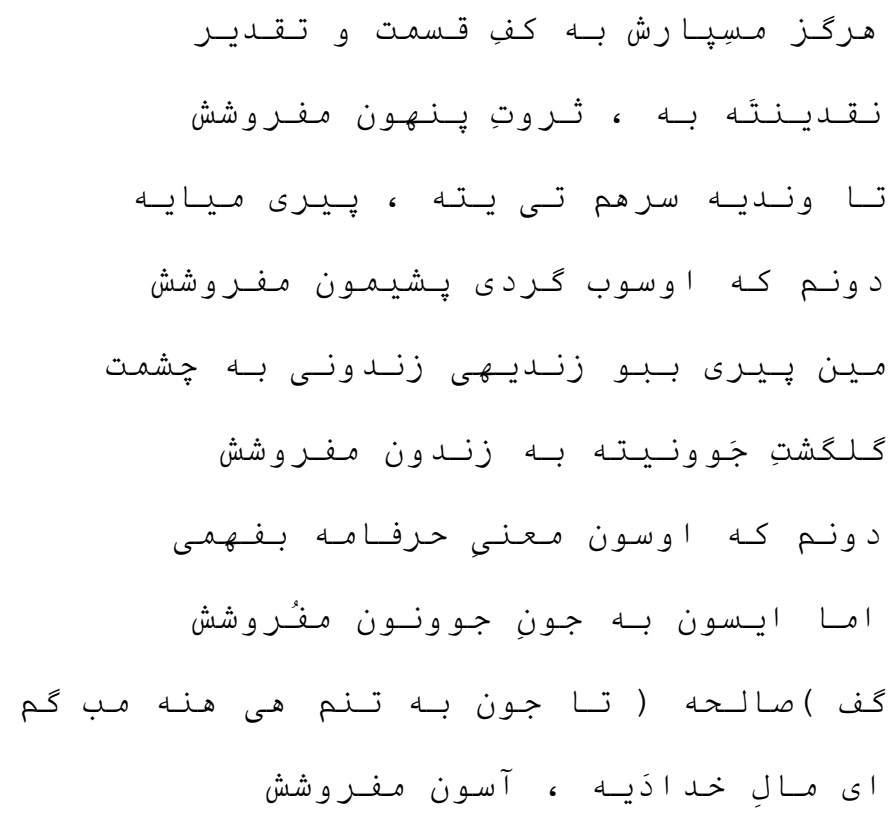

\section{REFERENCES}

Bonaffini, Luigi. “Translating Dialect Literature.” World Literature Today 71.2 (1997): 279-288. Print.

Mehdi-Abadi, Mohammad Ali. Dibaye Shoushtar: Ash'are Mahalie Shoushtari (An Introduction to Shoushtar: Shoushtari Local poems). Tehran: Sibe Sabz. 1381 (2002): 88. Print.

Yule, George. The Study of Language: Fourth Edition. Cambridge. Cambridge University, 2010. Print. 